\title{
From Universalism to Managerial Coordination: Major Power Regulation of the Use of Force
}

\author{
KONSTANTINOS TRAVLOS*
}

\begin{abstract}
Cooperation among major powers in order to regulate an aspect of international relations has been central to questions of global governance. In peace science the focus has been on the efficacy of major power regulation of the use of force. However, fruitful study requires variables that can capture the quality of major power regulation of the use of force. To provide such an instrument I use Peter Wallensteen's "universalism-particularism" variable-concept as the foundation. On it I built the concept of managerial coordination and the instrument that captures its quality, the scale of interstate managerial coordination (IMaC). Using IMaC, puzzling prior findings concerning major power regulation and minor power conflict are shown to be artifacts of operationalization.
\end{abstract}

Keywords: Major Powers, Regulation, International Regimes,

Diplomacy, War, Universalism, Militarized

Disputes, Peace

* Assistant Professor, Ozyegin University, Istanbul, Turkey;

E-mail: konstantinos.travlos@ozyegin.edu.tr

DOI: 10.16934/isr.17.2.201612.27 


\section{INTRODUCTION}

The anemic major power reaction to the ongoing conflict in Yemen is a strong reminder of the cost of major power antagonism. The US support for Saudi Arabia, and Russian support for Iran which backs the Houthi rebels, has given the conflict the character of a proxy war. In contrast, the same region 170 years ago experienced decisive regulatory intervention by the major powers that ended the Second Egyptian-Ottoman War. This was a multilateral intervention, despite competing major power interests. The powers were able to manage their differences and then manage the dispute. The difference between these two cases is a good example of the dichotomy inherent in the concepts of "universalism-particularism" developed by Peter Wallensteen (1984). ${ }^{1}$

Wallensteen argued that "universalism" existed when the major powers eschewed the particular advantages of unilateral activity, and instead endeavored to coordinate with the other major powers in order to regulate international relations. However, "particularism," the lack of such a policy, should be associated with an increase in the use of force. The 1840's were a period of "universalism," while the last decade has seen an increase in major power "particularism." This difference of regulatory framework can have human costs, as the difference between the two Middle Eastern crises exemplifies.

Despite the theoretical and empirical importance of "universalism-particularism," the concepts are in need of an update. The original concepts lacked a developed theoretical link between concept and operationalization, and the operationalization has issues of granularity, replicability, reliability, and temporal domain. These problems restrict the usefulness of "universalism-particularism" for the contemporary and historical study of conflict dynamics. Furthermore, I explain how the old operationalization led to a mistaken empirical conclusion. Early statistical research found that while "universalism" was associated with peace among the major powers, it was not associated with peace among minor powers, between major and minor powers, and between major powers and non-state polities (Wallensteen 1984; Schahczenski 1991). By using a more sophisticated measure this older finding becomes more nuanced, showing that "universalism" tends to also be associated with a decrease in the likelihood of major-minor, and minorminor wars.

To address these issues I endeavor a progressive shift by enriching "universalism-particularism" via the concept of managerial coordination. This richer conceptualization of the continuum between policies of "universalism" and "particularism" is then used as a foundation for a new measurement instrument, the scale of interstate managerial coordination (IMaC). These updates increase granularity, replicability, and temporal domain compared to the original operationalization. ${ }^{2}$ By using IMaC in replications of the original studies that found that 
"universalism" is not associated with major-minor, and minor-minor peace, I find indicators that the results were driven by operationalization, rather than empirical reality.

This manuscript is part of a broader project focused on the exploration of the causes and consequences of managerial coordination via the use of IMaC. The main objective here is to establish managerial coordination, and the measurement instrument associated with it, IMaC, as necessary and fruitful updates of the "universalism-particularism" concept. I show that this is the case theoretically but also empirically, using IMaC to clarify puzzling findings of the older literature. I do not expand fully on the theoretical stories of the causes and consequences of managerial coordination. Previous studies have touched on this (Travlos 2014), and new ones must follow, rather than be prior or contemporaneous with the establishment of a measurement instrument of managerial coordination.

\section{THE LEGACY OF "UNIVERSALISM-PARTICULARISM"}

Wallensteen's concept is an example of system level configurational variables (Zinnes 1980). These are the network of political actions states use for managing the political consequences of the distribution of structural attributes- the political culture of the system (Vasquez 1983). Different political cultures can foster war or peace, depending on what alternatives to war they offer. In this case "universalism" is pacific, and "particularism" bellicose. His argument was a probabilistic one, focusing on factors that made war less or more likely. Neither "universalism" or particularism" exhausted the factors that determine the likely-hood of war. But they were part of the story behind war and peace.

Wallensteen evaluated this dichotomy and found that periods of "universalism" did indeed see less major power war than periods of "particularism" (1984). Thanks to this finding, the concept influenced several subsequent studies of peace and conflict as a systemic factor contributing to peace (Gochman 1993; Raymond 1997; Vasquez and Gibler 2001; Siverson and Ward 2000; Chan 2005; Delahunty 2007; Senese and Vasquez 2008; Vasquez and Kang 2012; Valeriano and Maness 2015). There were also numerous studies that used the "universalismparticularism" variable in empirical evaluations.

The first empirical evaluation using "universalism" and "particularism" was by Schahczenski (1991). Schahczenski cautioned against assuming a causal relationship between "universalism-particularism" and peace and war. He argues instead that what Wallensteen offered was a periodization schema, not an explanatory concept. To show that universalism was not necessarily associated with pacific international relations he analyzed major power and minor power war and various militarized interstate dispute (MID) indictors by periods of "universalism" and "particularism." His findings largely confirmed those of Wallensteen. Crucially he 
found that "universalism" was not associated with the pacification of minor power conflict and extra-state warfare.

Despite the argument by Schahczenski, other researchers have found strong indicators that there is some association between "universalism" and decreases in conflict fostering international behavior. Valeriano revisited Wallensteen's concepts in his critical evaluation of offensive realism (2001). He found that the likelihood of major power dyads engaging in conflict was lower during "universalism" compared with "particularism." Vasquez found indicators that territorial disputes and arms races were less likely to take place in periods of "universalism" compared to periods of "particularism" (2001). The concepts were also applied outside traditional conflict studies, in analyses of globalization and armed conflict (Buhaug and Gleditsch 2006), and asymmetrical territorial conflict (Resnick 2013).

These studies are indicative of the analytical potential of the concept. Using Wallensteen's concept they all provide indicators of the importance and efficacy of major power regulatory regimes. They all indicate that system level factors can impact the decisions of war and peace. Simultaneously they also bring forth the limitations of the current operationalization, one that has not kept pace with the increasing sophistication of quantitative conflict analysis. The main culprit is the use of expert opinion, and the connection between the variables and the mechanisms of the conceptual story.

Wallensteen's analysis of what "universalism" entailed in policies was abstract. He does use the Geopolitk-Realpolitik-Idealpolitk-Kapitalopolitik framework to differentiate behavior in the two different periods, but this was executed inductively. The analysis sought to show how the periods were different, instead of why they were different $(1984,252-253)$. It is from this difference that Schahczenski built his periodization against explanation argument. This is not completely correct, as Wallensteen does spend time explaining the dynamics of each specific period, and why there are differences between major power relations and mixed status/minor power relations. However, these are not represented in the binary variable, nor is there an explanatory story about how "universalist" policies foster peace.

Empirically, the binary nature of the variable restricts its ability to capture variation in major power behavior. Wallensteen does note differences among periods of "universalism," but these are not apparent at the coding stage. The variable lacks the granularity to capture such variations in "universalism." The procedure that produced the variable-a non-random, non-structured survey of a small sample of expert opinion- is not readily replicable. ${ }^{3}$ Furthermore, it restricts the temporal domain of any study using the variables to the 1815-1976 period. Expanding it would require further use of expert opinion. These issues restrict how useful this variable can be.

To build an instrument that better captures empirical variations, we need to 
conceptually modify the "universalism-particularism" concept to predict more variation. To do this I use the concept of managerial coordination. This concept captures a specific empirical form of "universalism," engagement in consultation, multilateralism, and the avoidance of adversarial coordination. The combination of these three behaviors provides a larger variety of conceptual states of the world than the binary "univeralism-particularism" concept. These states of the world are then operationalized via the Scale of Interstate Managerial Coordination (IMaC). The resultant six point instrument captures more variations of "universalism" and "particularism" compared to the original binary variable. I compile it based on extant datasets, enhancing replication, and expanding the temporal domain to the 1715-2010 period.

The need to update the concepts is made necessary by the singular role that "universalism-particularism" fills for the study of international conflict. It is one of the few system level variables trying to capture the quality of major power regulation of the use of force in a holistic way. Most other variables that look at the regulation of the use of force at the system level either focus on the number of intergovernmental organizations, summitry, or the particular action of individual major powers. Few take all of these together like "universalism" and "particularism." Furthermore, available system level variables like those of Braumoeller (2012) or Boix (2011) focus on other aspects of the status quo than the use of force.

Braumoeller's instrument focuses on the distribution of material capabilities, and the distribution of political regimes as proxies for the status quo (2012). These are proxies for the relative position of major powers in the system level status quo. They are not indicators of whether the major powers endeavor to manage the use of force in the system or not. Wallensteen's concept addresses that. Boix's instrument focuses on the interaction between the distribution of political regimes in the system and major power alliance portfolios (2011). Its main goal is to capture the degree to which the system is polarized along regime lines. While this is a factor that can affect managerial coordination, this is not an instrument that captures managerial coordination. Ideological polarization might affect how major powers regulate force, but is not what regulates force.

This is important. While all dimensions of the status quo are interrelated, the tools that are used to regulate one aspect may not be applicable to others, and whether the regulation of the distribution of material capabilities or of political regimes shall be pacific or not is contingent on the regulation of the use of force. Only Wallensteen's concept tried to touch on this dimension, and for this reason it is worthwhile updating it via major power managerial coordination.

Before continuing it would be useful to tease out the limits of the concept of interstate managerial coordination. Like "universalism-particularism" the concept focuses on interstate conflict. There are two reasons for this. First, most of the past 
examples of these activities were tied to the avoidance of interstate war. This is the case with the Vienna System, the League of Nations, and the initial creation of the United Nations. This does not mean that the regimes were not used to regulate state interventions in civil wars (whether intra-state or non-state conflicts). But their main focus was on regulating interstate war.

Second, in the case of non-state wars, labeled "new wars" by part of the literature, interstate managerial coordination might not be an appropriate tool. ${ }^{4}$ These wars, whether "new" or pre-modern, predominate in regions of the world where the state has not been able to impose its monopoly of the use of legitimate violence. Interstate managerial coordination is a tool developed to address the regulation of interstate war. In another name it will rise among states that have resolved the issue of the monopoly of the use force, restricting war to interstate war, and then trying to regulate that. It is thus unlikely to affect the incidence of non-state wars. ${ }^{5}$ Instead any influence will be focused on restricting the conesquences of state intervention in such wars on the likelihood of interstate war. The empirical consequences of interstate managerial coordination for interstate and non-state wars will be different. In this paper the main focus is on interstate wars.

\section{MANAGERIAL COORDINATION AND WAR}

The concept of major power coordination stems from considering how antagonistic major powers foster international conflict (Chiba et al. 2014). I will briefly discuss the theories of war here which underpin the theory of peace behind the concept of managerial coordination. This is a summary of a more expanded discussion conducted in Travlos (2014).

I begin with Braumoeller's story about why the major powers engage in foreign policy activity that may include war (Braumoeller 2012). They do so in order to adjust the status quo to satisfy the winning coalition that supports the elites in government (Bueno De Mesquita et al. 2003). This movement of the status quo will then hurt the winning coalitions of other powers, creating domestic pressure for reaction and leading to countervailing activity. As long as the costs of the current status quo are higher for the position of elites in government than the costs of foreign policy adventurism and war, they will be willing to hazard war. War can be the result of an explicit demand of the winning coalition, or of a conflict spiral that develops from the activity of the major powers (Herz 1950; Jervis 1978).

The conflict spiral does not lead to war because the situation gets out of control. Instead, the process is the one mapped out by the Steps to War program (Senese and Vasquez 2008). The engagement by major powers in realpolitik, legitimizes hardliner positions on the use of force domestically. More importantly, the conflict spiral leads to the replacement of accommodationists by hardliners 
among elites in government, either due to expulsion or transformation. In this way, the decision-making process of more than one major power becomes dominated by hardliners which is the sufficient condition for the outbreak of war. This process is well exemplified by Clark's recent narrative of the outbreak of the First World War and discussed in the recent Levy and Vasquez edited volume (Clark 2012; Levy and Vasquez 2014).

These conflict-fostering conditions among the major powers will diffuse to the broader interstate system. First, in many cases the dissatisfaction of members of the winning coalition with the status quo is focused on relations between the major powers and minor powers. Consequently, some of the foreign policy activity tracked by Braumoeller is targeted towards minor powers. That includes realpolitik activity that fosters war (Senese and Vasquez 2008). This direct intervention is one way in which minor powers are linked to major power conflict spirals.

The other two ways are by facilitation and protection. For major powers engaged in acute competition, minor powers can be useful allies, brining additional resources to their disposal. Furthermore, support for a minor power can be used as leverage for gaining the support of another major power. Major powers can support minor powers by facilitation, which entails material and financial support for the foreign policy of a minor power. This makes the use of force cheaper and can foster foreign adventurism, which can trigger counter-support by other major powers for the targets of that adventurism. This feeds conflict spirals. An example of facilitation is French and Russian financial and military transfers to Serbia in the 1910-1914 period.

Protection, the other way major powers can support minor powers, refers to the use of the dominant position by major powers in international regimes in order to protect minor powers from international censure. It is not deterrence; as it is not targeted against military action. Instead, it consists of helping minor powers avoid the diplomatic costs of their activity. Stated simply, it protects them from the status of pariah. US support for Israel in international fora is such an example. A result of this activity is the hallowing of international regimes, rendering potential alternatives to the use of force moot and thus further fostering the progress of states along the Steps to War.

These activities of major powers that foster conflict create large networks of linked disputes that foster the escalation and diffusion of war (Vasquez 1993; Senese and Vasquez 2008). These linked conflicts increase the likelihood of complex major power wars (Valeriano and Vasquez 2010). In turn these massive conflicts can threaten the dominant domestic position of major power elites. War may lead to war-weary constituencies overthrowing the governments that led them into it. It may also fan the fires of social revolution. Wallensteen noted that most periods of "universalism" were preceded by large scale major power war, often accompanied by radical regime changes in major powers (1984, 253-255). Expe- 
rience of such a war may lead major power elites in government to consider the costs of the current status quo much smaller than the potential costs of wars to change it. It may also lead to a decrease in the presence of hardliners in both the elites in government and the winning coalition. Finally, it may also motivate restrictions on the use of force among major powers as a way to safeguard their domestic dominant position (Jervis 1985; Schroeder 1994; Travlos 2014).

A problem arises from this story. If all the major powers, or the majority of them, have elites in government that are averse to war, then that is sufficient to avert war in light of the story of war that underlies this paper. The creation of a regime might be useful for the facilitation of major power diplomacy, but it is not a factor that fosters peace. The aversion to war of major power elites does that. Consequently, aversion to war is a necessary but not sufficient condition for managerial coordination. However, the end of a war does not freeze politics.

Even if the major powers are engaged in friendly relations, conflict outside their network can lead to changes in the winning coalition that may undermine that amity. Conflict among the minor powers, and major-minor conflict, may create space for the legitimization of hardliner policies within the winning coalition of major powers. These may lead to demands for increased foreign policy activity, which can lead to a conflict spiral that puts the major powers back into the steps to war. This is exacerbated by the inherent lag in foreign policy. The networks of facilitation and protection created by the major powers during periods of "particularism" may last well into periods of "universalism." This can create linkages that can be exploited by hardliners to overthrow a policy of major power peace. Put simply, what happens among, and to, minor powers can affect the ability of major powers to keep the peace among themselves. ${ }^{6}$

This need to manage the potential consequences of minor power relations, and major-minor relations, in order to protect major power peace makes it more likely that major power elites in government will engage in managerial coordination. This is a probabilistic, not deterministic process. If the major powers are able to insulate themselves from minor powers quite easily, then they will have less incentive to engage in managerial coordination. That said, if they cannot successfully insulate, and the major power elites are characterized by aversion to war, they will be more likely to engage in managerial coordination. The goal of managerial coordination is to facilitate coordination among the major powers in order to decrease the use of force in the international system, and thus dampen the rise of hardliners within their winning coalitions that can threaten major power peace.

Managerial coordination entails the engagement of major powers in three complementary but distinct sets of activities. Each one by itself has a probability of decreasing the likelihood of the use of military force in interstate relations. Engagement in all is a necessary and sufficient condition for a managerial regime, which has an even greater probability of decreasing the likelihood of the use of 
military force in interstate relations. This is because these activities can dampen factors that foster conflict. These are i) uncertainty about the preferences of the various major powers on the resolution of the issue at stake (Jervis 1985, 75); ii) the fear of unilateral action by major powers either by direct intervention in support of a disputant, or by facilitation-protection policies (Steiner 2004); and iii) the lack of credible alternatives to the use of force for resolving the issue at stake (Vasquez 1993).

The first set of activities is Consultation. This is activities of regularized exchange of views and ideas on international issues. The goal is to decrease uncertainty over major power preferences over the resolution of an issue. At the very least consultation can facilitate policies of insulation (Steiner 2004, 193). Refusal to engage in consultation is in and itself a powerful signal to the other major powers and minor powers. Thus, despite being a "cheap" policy from the point of view of major power foreign policy freedom, it can help clarify some basic information about major power intentions in a crisis, and at least permit a first policy in defense of major power peace.

The second set of activities is Multilateralism. This entails discussion for the coordination of major power activity with the goal of resolving an issue in a manner conducive to the pacific maintenance of the status quo among the powers. The goal is to decrease the likelihood of unilateral activity by major powers, which increases the likelihood of unforeseen escalation and diffusion (Jervis 1985, 71-72, 73-76). It also provides a credible alternative to the use of force, in the form of major power coordinated activity. It is the more activist alternative to insulation.

Finally, the major powers must dismantle the system of adversarial alliances that dominated their relationships before their decision to engage in managerial coordination. Avoiding overt adversarial alliances is a signal to minor powers that they cannot rely on major power adversarial relationships for succor. It is also necessary for the functioning of multilateralism as a credible alternative to the use of force (Richardson 1993: 228-230; Jervis 1985, 73). The existence of such alliances provides a signal of major power particularism to minor powers, opening the way for policies of facilitation and protection, which can increase the likelihood of interstate conflict.

A historical example of consultation is the Vienna Congress System between 1816 and 1848. An example of multilateralism was the Quadruple alliance from 1818 to 1822 after France was made a de-facto member. Examples of adversarial alliances were the Triple Entente and Triple Alliance. These three sets of activities increase the ability of the major powers to make the efficient choice in Jervis concert formation Prisoner's Dilemma game (1992, 720-721). Combining all three creates a major power managerial coordination regime which is the highest form of "universalism" possible in an anarchic international system.

The specific mechanisms by which major power managerial coordination 
influences the decision of minor powers to pursue an adventurous policy, and restricts the ability of major power domestic hardliners to support such policies, are denial and discouragement. Discouragement includes any policies by the coordinating major powers that threaten to increase the costs of an adventurous foreign policy. These can vary from economic and political sanctions, to direct military interventions. Denial includes all policies by the coordinating major powers that deny adventurous minor powers support for their policy, or the benefits of such a policy. These can vary from what Steiner terms insulation policies, the denial of facilitation and protection policies, and reach policies such the nonrecognition of territorial changes (Steiner 2004). Preliminary work on these two mechanisms indicates the superiority of denial to discouragement policies (Travlos 2014).

The engagement of the major powers in combinations of consultation, multilateralism, and avoidance of adversarial coordination varies. It is this variation that the scale of interstate managerial coordination (IMaC) tries to capture. It should be noted here that while I focus on the use of managerial coordination between the major powers, the principles can also be applied to minor powers.

\section{THE SCALE OF INTERSTATE MANAGERIAL COORDINATION (IMaC)}

The main variable of interest in this project is the variation in collective major power regulation of the use of force in the international system. The goal is to capture, using IMaC, whether major power interaction is characterized by policies in pursuit of antagonism or by attempts at managerial coordination. It does so by capturing collective major power participation in consultation, multilateralism, and in the avoidance of adversarial coordination. The more powers that participate, the stronger managerial coordination is; thus fostering "universalism." The fewer that do so, the weaker it is, fostering "particularism."

First, we need to operationalize each element of managerial coordination. Briefly, I operationalize consultation as the shared membership of the major powers in intergovernmental organizations with a security mandate, like the UN. I also include membership in large congresses that try to resolve international issues by creating informal regimes and norms, like the Berlin Congresses. I count consultation as existent if at least all major powers except for one are members. Membership in such regimes, whatever the motives behind it, tends to lock-in at least some norms for managing issues within the confines of the status quo. The powers essentially project a picture (purposeful or not) of adhering to the constitution of international relations created by the congress (Randle 1987). Deviation from this picture will be costly, as the deviant is likely to be branded a pariah.

I operationalize multilateralism by the shared membership of the major 
powers in alliances that do not officially target a non-member major power. Alliances are defined according to the Alliance Treaty Provision project definition for the post-1815 period and according to Gibler for the pre-1815 period (1999). I consider multilateralism to exist if at least all major powers except for one are members. Membership in such an alliance is a powerful indicator of the preference of major powers for consultation, but also for coordinated action in resolving conflicts. This is because such alliances are both hard to create, and costly in foreign policy freedom. Major power allies are not as easily ignored as minor power allies.

Consultation and multilateralism are coded for the participation of major powers. Concerning avoidance of adversarial coordination, I code the failure of the major powers to succeed in this. I do this because I operationalize adversarial coordination before 1945 by major power membership in major power alliances that officially target a non-member major power. Since alliances are rare events, coding their avoidance would produce an overabundance of positives. Instead, I prefer to capture the failure of major powers to avoid adversarial coordination, which is a powerful indicator of enmity and "particularism." This is the case if at least one alliance of such a character exists in the system between at least two major powers. Alliances are coded by ATOP-Gibler definitions.

I cannot use such alliances as an operationalization in the post-1945 period. This is because the UN Charter norm of the illegality of offensive alliances, has led states to avoid overt stipulations of targets in alliance provisions. ${ }^{7}$ The adversarial character is implicit, not explicit, which raises issues of reliability in using them as indicators of adversarial coordination. This norm holds even for legal defensive pacts. Consequently, an alternative operational variable is needed after 1945.

This alternative is Linked Strategic Rivalries (Colaresi et al. 2008). Strategic Rivalry is a condition during which two states exhibit rhetoric and policy activity that indicates mutual perceptions of threat. It is a weaker identifier of enmity than adversarial alliances due to the lack of the connection that alliances have between threat and military means. However, it still entails open declarations of enmity.

The problem is that strategic rivalry can last for a very long time, including multiple centuries. Not all those periods are characterized by heightened enmity. What is needed is a way to capture periods of intense adversarial coordination within strategic rivalries. The answer is linked rivalries. In these cases two states that have the same strategic rival, link their rivalries via alliance. While there may be no overt declarations of hostility, the coordination of the policies of the two states is more likely to be considered adversarial by their common rival. Consequently, after 1945, I use major power linked strategic rivalry as the operationalization for adversarial coordination

I consider consultation and multilateralism equal and complementary in effect. Consultation is necessary for Multilateralism, and in the absence of Multilatera- 
lism, Consultation has a muted impact, at most fostering insulation. The presence of both results in a pacific synergy. Adversarial coordination will always have a stronger influence than each of the cooperative sets of activities by themselves. In the case of consultation, the existence of adversarial alliances places a clear limit on what is a permissible topic of discussion. The state of Crete in 1897 was a permissible topic during coordination activity on the Eastern Question. The Austrian annexation of Bosnia-Herzegovina was not. Consequently, adversarial coordination bounds consultation. Multilateralism is similarly limited. The Powers may have been willing to intervene multilaterally against China in 1900, but they would never have agreed on an intervention against the Balkan allies in 1912, where the stakes were directly tied to their enmity.

The presence of both consultation and multilateralism should provide enough tools for the major powers to facilitate coordination even in the shadow of enmity. What this means is that within the bounds created by adversarial coordination, the major powers should be more efficient in their managerial efforts when both cooperative sets of activities are present. This coordination will still be inferior to that done in the absence of adversarial coordination.

To capture these dynamics I code in each system year the presence of consultation, multilateralism, or failure to avoid adversarial coordination. Consultation is coded (1), multilateralism is coded (1), and failure to avoid adversarial coordination is coded (-1.5). When one combines the scores per year the result is the annual value of managerial coordination. This way, the combined influence of consultation and multilateralism will give a positive score even in the face of adversarial coordination, but in isolation each one will not preclude a negative score in the presence of adversarial coordination.

The combination of the three variables creates a scale of six categories that correspond to the six possible values of their summation. Categories are ranked from highest level of engagement in regulation to lowest. The combinations are tabulated in Table 1. To facilitate statistical work I add a 2 to the final value for each year, so that the scale has a minimum of 0.5 and a maximum of 4 , instead of 1.5 and 2. Each numerical category is also given a name, and an exemplary case.

Wallensteen's concept of "Universalism" is best represented by the category "Universalist Regime," which is characterized by a managerial regime made up by avoidance of adversarial alliances, and consultation and multilateralism. The exemplary case is the Vienna System between 1816 and 1822. "Managerial Regulation" represents periods in which the major powers are only engaged in consultation or multilateralism, but still avoid adversarial coordination. It is the most common form of regulatory regime by the major powers. The exemplary case is the Later Vienna System between 1841 and 1853.

"Bounded Regulation" and "Anemic Regulation" represent the gray area between "universalism" and "particularism" that Wallensteen's binary variables 
did not capture. These are periods of either major power engagement in both consultation and multilateralism but also failure to avoid adversarial coordination. They also include periods without adversarial coordination in which participation in consultation or multilateralism is done by the minority of major powers. These are not periods of unrestrained conflict, but they are also not periods of efficient regulation. The League of Nations is the anchor case, since for most of its period the US and USSR were not members.

\section{TABLE 1.The SCALE OF Interstate Managerial COORdination (IMAC)}

\begin{tabular}{|c|c|c|c|c|c|}
\hline $\begin{array}{l}\text { Coordination } \\
\text { Category } \\
\text { Name }\end{array}$ & $\begin{array}{c}\text { Coordination } \\
\text { Category } \\
\text { Value } \\
\text { (linear } \\
\text { adjustment) }\end{array}$ & $\begin{array}{c}\text { Managerial } \\
\text { Alliance } \\
\text { (Multilateralism) } \\
\text { 1: Present } \\
\text { 0: Absent }\end{array}$ & $\begin{array}{l}\text { Shared Membership } \\
\text { in International } \\
\text { Pacific Institutions } \\
\text { and Regimes } \\
\text { (Consultation) } \\
\text { 1: Present } \\
0: \text { Absent } \\
\end{array}$ & $\begin{array}{l}\text { Adversarial } \\
\text { Alliances } \\
\text { (Adversarial } \\
\text { Coordination) } \\
\text {-1.5: Present } \\
0: \text { Absent }\end{array}$ & Example \\
\hline $\begin{array}{l}\text { "Universalist } \\
\text { Regime" }\end{array}$ & $2(4)=$ & 1 & 1 & 0 & \multirow{5}{*}{$\begin{array}{l}\text { Early Vienna } \\
\text { Congress } \\
1816-1822 \\
\text { Later Vienna } \\
\text { Congress } \\
\mathbf{1 8 4 1 - 1 8 5 3} \\
\text { N/A in 1715- } \\
2010 \\
\text { League of } \\
\text { Nations } \\
\mathbf{1 9 2 2 - 1 9 3 4}\end{array}$} \\
\hline \multirow{2}{*}{$\begin{array}{l}\text { "Managerial } \\
\text { Regulation" }\end{array}$} & $1(3)=$ & 1 & 0 & 0 & \\
\hline & $1(3)=$ & 0 & 1 & 0 & \\
\hline $\begin{array}{l}\text { "Bounded } \\
\text { Regulation" }\end{array}$ & $0.5(2.5)=$ & 1 & 1 & -1.5 & \\
\hline $\begin{array}{l}\text { "Anemic } \\
\text { Regulation" }\end{array}$ & $0(2)=$ & 0 & 0 & $\mathbf{0}$ & \\
\hline \multirow{2}{*}{$\begin{array}{l}\text { "Particularist } \\
\text { Regulation" }\end{array}$} & $-0.5(1.5)=$ & 1 & 0 & -1.5 & \multirow{2}{*}{$\begin{array}{l}\text { Detente Cold } \\
\text { War Period } \\
1971-1989\end{array}$} \\
\hline & $-0.5(1.5)=$ & 0 & 1 & -1.5 & \\
\hline $\begin{array}{l}\text { "Adversarial } \\
\text { Particularism" }\end{array}$ & $-1.5(0.5)=$ & $\mathbf{0}$ & $\mathbf{0}$ & -1.5 & $\begin{array}{l}\text { Main Cold } \\
\text { War Period } \\
\text { 1950-1970 }\end{array}$ \\
\hline
\end{tabular}

The last two categories best exemplify Wallensteen's concept of "Particularism." "Particularistic Regulation" represents periods during which the major powers are engaged in one of the two cooperative sets of activities of managerial coordination, but have failed to avoid adversarial alliances. This usually means that any attempts at using regulatory mechanisms are in the pursuit of the particularistic goals of the major powers instead of the decrease of international conflict. It is a period of cooperation among adversaries like the Cold War Détente. "Adversarial Particularism" represents periods when the major powers are exclusively engaged in adversarial coordination. The early cold war period between 1950 and 1971 is an example of this.

It should be noted that IMaC does not measure peace among the Major Powers. By the theory of war underlying this discussion, and presented above, major powers engage in managerial coordination when they are already primed for peace. Instead, 
managerial coordination tries to capture the attempt of the major powers to safeguard their peace from the consequences of actions taken outside their immediate circle of peers.

An objection that has been raised to the whole concept of managerial coordination is that it is an endogenous factor to the intentions of major powers to wish for peace. First, considering that intentions are a non-empirical quantity, the fact that managerial coordination may be a direct manifestation of those is a benefit not a problem. Endogeneity ultimately is a question of the interaction of empirical variables. In this case we have a variable interacting with an abstract concept. Second, there are reasons to question the endogeneity argument. Major Powers with pacific intentions can affect the system through multiple ways. Managerial coordination is only one of them. Yes, good intentions are a necessary condition for the rise of Managerial Coordination, yet it is not sufficient as noted in the theoretical sketch.

\section{OPERATIONALIZATION OF IMaC}

The temporal range of the scale is the $1715-2010$ period, restricted due to current data availability. Major power status for 1816-2010 is taken from the Correlates of War Major Power dataset (COW Major 2011). ${ }^{8}$ For 1715-1815 I rely on the Levy list of major powers (Gibler 1999).

For 1816-2010, alliance membership is taken from the Alliance Participant dataset of the Alliance Treaty Obligations Provision project (ATOP.3). I use it to locate major power managerial alliances and major power adversarial alliances. There are 3 major power managerial alliances in the 1816-2010 period. ${ }^{9}$ There are 23 adversarial alliances in the same period. ${ }^{10}$ For $1715-1815$ I coded the two types of alliances using the data and documentation provided by Gibler (1999). In this period there were 12 adversarial alliances and 0 managerial alliances. ${ }^{11}$

A number of objections have been raised in the past against the use of managerial alliances as the operationalization of multilateralism. First is the argument that alliances cannot have a systemic effect. They can only affect the states within the alliance. Such an argument discounts the role of major powers in constituting the international system (Braumoeller 2012). Because of that role the alliances of major powers, and especially those that include almost all the major powers, will have a broader systemic impact beyond that of their members.

Another objection is that managerial and adversarial alliances capture the same dynamics. They do not. Managerial alliances are driven by a regulatory impetus. Their goal is to permit the major powers to act as a collective. The goal is to foster multilateral major power action. Adversarial alliances are driven by particularism. The goal is to enhance the ability of each member to engage in unilateral activity. The two are not opposite sides of the same coin. A major power can 
engage in both at the same time. Instead, they are different foreign policy tools for major powers. Engaging in both dampens the efficiency of each separate tool, but does not negate their usefulness. Instead, it permits a bounded regulation: one that major powers can use to avoid unwanted escalations, with the adversarial alliances giving confidence that they can win any purposeful escalation.

Finally, the focus on the explicit targeting of non-member major powers for adversarial alliances raises the possibility of undercounting cases of adversarial coordination by missing alliances that implicitly targeted a non-member major power, especially in the post-1945 period. This is not an issue. ATOP documenttation is useful in noting if an alliance had an implicit adversarial character. Furthermore, in the pre- 1945 period such alliances would be problematic as strong indicators of adversarial relations. The lack of an explicit clause concerning targeting undermines credibility and creates space for defections and claims of plausible deniability by opportunistic alliance members. Lastly, in the post-1945 period I use a different operationalization of avoidance of adversarial coordination.

After 1945 I cannot use adversarial alliances to operationalize adversarial coordination, since major power alliances with explicit targeting clauses do not exist. Instead I use major power linked strategic rivalries. I locate all major power strategic rivalries after 1945 (Colaresi et al. 2008). There were 7 such rivalries. ${ }^{12}$ I then use the ATOP project to locate major power alliances that link major powers with common rivals after 1945 . There are 15 potential cases. ${ }^{13}$ Bringing the two sets of information together we have the following Major Power Linked Strategic Rivalries. It should be noted that the term alliance here is the term as used by ATOP, not as it is used in common usage.

a) 1949-1950, Alliance 3030 (USSR-China) links the Soviet Union-US (19451989) and China-US Rivalries (1949-1972).

b) 1950-1972 (1980), Alliance 3200 (USSR-China) links the Soviet Union-US (1945-1989) and China-US Rivalries (1949-1972).

c) (1960)1996-2011, Alliance 3375 (USA-Japan) links the Japan-China (19962011), and China-Untied States (1996-2011) rivalries.

d) 1949-1956 (1989), Alliance 3180 (NATO, US-UK) links the Anglo-Soviet (1945-1956) and US-Soviet (1945-1989) Rivalries

e) 1962-1964, Alliance 3460 (China-US) links the Chinese-Soviet (1958-1989) and US-Soviet Rivalries (1945-1989)

The above list indicates the existence of major power linked strategic rivalries in 1949-1972 and 1996-2011.

To operationalize consultation, I use shared major power membership in intergovernmental pacific or security institutions. This was coded using data from the Multilateral Treaties of Pacific Settlement (MTOP) dataset v1.4 (Hensel 2001, 
2005). ${ }^{14}$ Only intergovernmental institutions that have a security mandate and have acted on that security mandate are included. This is because major power membership in intergovernmental institutions that have no mandate on politicalsecurity issues does not give any signal about member adherence to pacific managerial regimes. Membership in inactive institutions also provides no signal, as membership is not costly.

I locate active institutions using the lists compiled by Hansen, Mitchell and Nementh (2008) and Bercovitch and Schneider (2000). This produces a list of 20 active peace institutions in the 1816-2008 periods, which can be found in the Online Appendix. ${ }^{15}$ A review of the literature does not lead me to believe that the character of these regimes has changed in the 2008-2010 period.

Consultation also includes participation in large international congresses and peace treaties (like Westphalia in 1648). A major power is considered a member of such an informal institution if it took part in its inaugurating meeting or in subsequent meetings. I also count it as a member in the decade after the last meeting. This membership criterion comes from Randle's argument that membership in international congresses is also membership in the constitution of regimes created in them $(1987,32,35,59-61)$. The ten-year rule puts a limit to the potential pacific influence of the last meeting. If a new meeting within the regime does not take place within the last decade from the previous meeting, then at the end of that decade I assume the regime has become so weak as to stop having any influence.

I locate congresses using the list of constitutional events in the modern interstate system since the $16^{\text {th }}$ century compiled by Randle (1987). I only include those constitutional events that endeavored to create a system of regulation characterized by periodic meetings. I only include such congresses in which at least all major powers bar one participated, either in the initial or subsequent meetings. Congresses conducted under the aegis of intergovernmental institutions, for example the Locarno Treaties, are not counted as the sponsoring IGO is counted instead. There were no such IGOs in the 1715-1815 period. The treaties and congresses that meet the above requirements and the sources of membership information are presented in the Online Appendix.

Does consultation just capture the trend in increased IGO memberships in the system? No, because it is the major powers themselves that initiated this trend. The consultation of managerial coordination may have become more frequent as IGOs became a tool of statecraft, but it is prior to that trend, not a result of it. Table 2 summarizes the operationalization schema.

The distribution of values of IMaC in 1715-2010, created by the operationalization in Table 2, is presented in Figure 1.

In Table 3, I provide a more specific list of the number of years, and specific periods that fall within each category of IMaC.

Mapping IMaC over Wallensteen's binary instrument in the 1816-1976 
period shows the gains in greater granularity. The results are in Table 4.

TABLE 2. OPERATIONALIZING MANAGERIAL COORDINATION

\begin{tabular}{|c|c|c|c|}
\hline $\begin{array}{c}\text { Element of Managerial } \\
\text { Coordination }\end{array}$ & Variable & $\begin{array}{c}\text { Temporal } \\
\text { Range }\end{array}$ & Sources \\
\hline \multirow{2}{*}{ Multilateralism } & \multirow{2}{*}{$\begin{array}{l}\text { Major Power } \\
\text { Managerial Alliance }\end{array}$} & $1715-1815$ & Gibler 1999, 2010 \\
\hline & & $1816-2010$ & ATOP \\
\hline \multirow{3}{*}{ Consultation } & \multirow{2}{*}{$\begin{array}{l}\text { Membership in Active } \\
\text { IGOs }\end{array}$} & $1715-1815$ & None Exist \\
\hline & & $1816-2010$ & $\begin{array}{l}\text { Hansen et al. (2008); } \\
\text { Bercovitch and Schneider (2000) }\end{array}$ \\
\hline & $\begin{array}{l}\text { Membership in Peace } \\
\text { Congresses }\end{array}$ & $\begin{array}{l}1715-1815 \\
1816-2010\end{array}$ & Randle 1987 \\
\hline \multirow{3}{*}{$\begin{array}{l}\text { Adversarial } \\
\text { Coordination }\end{array}$} & \multirow{2}{*}{$\begin{array}{l}\text { Major Power } \\
\text { Adversarial Alliances }\end{array}$} & $1715-1815$ & Gibler 1999, 2010 \\
\hline & & $1816-1945$ & ATOP \\
\hline & $\begin{array}{l}\text { Major Power Linked } \\
\text { Strategic Rivalries }\end{array}$ & 1946-2010 & $\begin{array}{l}\text { ATOP and Colaresi } \\
\text { et al. (2008) }\end{array}$ \\
\hline
\end{tabular}

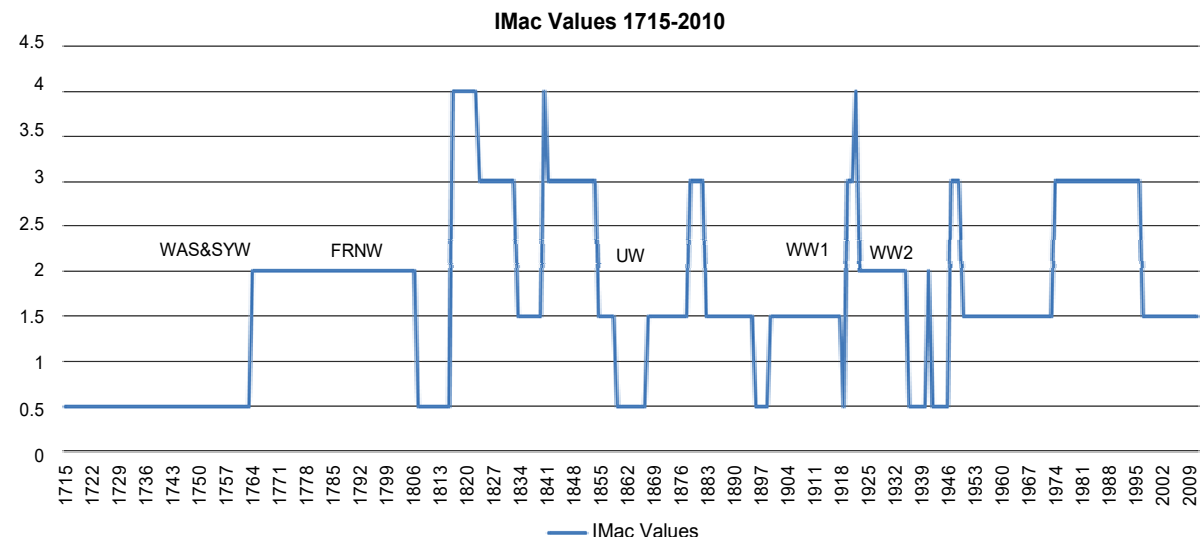

NOTES: WAS \& SYW: War of Austrian Succession and Seven Years War.

FRNW: French Revolutionary and Napoleonic Wars.

UW: Wars of German and Italian Unification.

WW1: World War 1/WW2: World War 2.

Figure 1. SCAlE OF MAJOR POWER COORDINATION IN THE 1715-2010 PERIOD

TABLE 3.NuMBER OF SYSTEM YEARS BY IMAC CATEGORIES 1715-2010

\begin{tabular}{lcl}
\hline IMaC category & $\begin{array}{c}\text { Number of Years in } \\
\text { 1715-2010 period }\end{array}$ & \multicolumn{1}{c}{ Years } \\
\hline "Adversarial Particularism" & 81 & $1715-1763,1807-1815,1859-1866$, \\
& & $1895-1898,1918,1935-1939,1941-1945$ \\
"Particularistic Regulation" & 94 & $\begin{array}{l}1833-1839,1854-1858,1867-1877, \\
1882-1894,1899-1917,1949-1972,1996-2010\end{array}$ \\
"Anemic Regulation" & 57 & $1764-1806,1922-1934,1940$. \\
"Bounded Regulation" & None & None \\
"Managerial Regulation" & 55 & $1823-1832,1841-1853,1878-1881,1919-$ \\
& & $1920,1946-1948,1973-1995$ \\
"Universalist Regulation" & 9 & $1816-1822,1827-1829,1840,1921$ \\
\hline
\end{tabular}


TABle 4. MAPPING “UNIVERSALISM” AND “PARTICULARISM” ON IMAC, 1816-1976

\begin{tabular}{lcc}
\hline \multicolumn{1}{c}{ IMaC Category } & Universalism Years & Particularism Years \\
\hline "Universalist Regime" & 9 & 0 \\
"Managerial Regulation" & 28 & 8 \\
"Bounded Regulation" & NA & NA \\
"Regulatory Indifference" & 11 & 3 \\
"Particularist Regulation" & 37 & 42 \\
"Adversarial Particularism" & 1 & 22 \\
\hline
\end{tabular}

Generally speaking, the extremes of the scale "Universalist Regime" and "Adversarial Particularism" map well with "universalism" and "particularism." However, the behaviors captured by the in-between levels tell a story much different to the binary original. While both "Managerial Regulation" and "Bounded Regulation" see a predominance of years of "universalism," both also contain years of "particularism." "Particularistic Regulation" is dominated by years of "particularism" but also has some years of "universalism." This complexity is logical as these categories capture major power activity that tries to balance between adversarial and managerial coordination. I argue that the Wallensteen and Schahczenski findings that "universalism" does not lead to peace in minor power relations, is driven by the fact that their binary variable missed the nuances revealed by the use of IMaC to capture the variation between "universalist" and "particularist" policies.

\section{EVALUATING VALIDITY}

Correlations indicate that each element of IMaC captures a distinct behavior. The maximum correlation between two sets of activities is $21 \%$, and covariance is less than 0.10 .

External validity is evaluated by a small set of tests using indicators of the use of international force among the major powers. These are the onset of major power wars and major power rivalries, as these are behaviors that managerial coordination should inhibit. If the explanatory story behind managerial coordination is valid, "Universalist Regime" and "Managerial Coordination" should not be characterized by major power wars or the onsets of rivalry.

I use the Correlates of War data for the 1816-2010 period, and the Levy Great Power War data for the 1715-1815 (1994), to locate major power war onsets. I use the Klein, Goertz and Diehl conceptualization to locate major power rivalry onsets in the 1816-2010 period (2006). I then tabulate onset frequency for war and rivalry, on the six categories of IMaC. The results are in Table 5. The results indicate that wars between major powers tend to occur within those categories of the scale that are characterized by the absence of managerial coordination. 
TABLE 5. IMAC AND WAR AND RIVALRY ONSET

\begin{tabular}{lcccc}
\hline \multicolumn{1}{c}{ IMaC Scale } & $\begin{array}{c}\text { Number of Major } \\
\text { Power War Onsets }\end{array}$ & Percentage & $\begin{array}{c}\text { Number of } \\
\text { Rivalry Onsets }\end{array}$ & Percentage \\
\hline "Universalist Regime" & 0 & $0 \%$ & 3 & $2.5 \%$ \\
"Managerial Regulation" & 0 & $0 \%$ & 35 & $30 \%$ \\
"Bounded Regulation" & $\mathrm{NA}$ & $\mathrm{NA}$ & $\mathrm{NA}$ & $\mathrm{NA}$ \\
"Regulatory Indifference" & 4 & $19 \%$ & 5 & $4 \%$ \\
"Particularistic Regulation" & 5 & $25 \%$ & 61 & $52.5 \%$ \\
"Adversarial Particularism" & 9 & $56 \%$ & 13 & $11 \%$ \\
$\quad$ Totals & 18 & $100 \%$ & 117 & $100 \%$ \\
\hline
\end{tabular}

Eighty percent of wars take place in periods of "Particularistic Regulation" and "Adversarial Particularism." None take place in periods of "Universalist Regime" or "Managerial Regulation." We also notice that the vast majority of rivalry onsets, about $60 \%$, take part during system years which are characterized by a lack of engagement in the cooperative sets of activities of managerial coordination. Increasing managerial coordination does correspond to an unwillingness of the major powers to use force amongst themselves.

The question to address now is whether the use of IMaC can lead to insights which the use of the old variable obscured. To do this I revisit the analyses done by Wallensteen (1984), and Schahczenski (1991).

\section{UNIVERSLAIM, IMaC AND MINOR POWER CONFLICT}

I argue that prior findings that cast doubt on the pacific influence of "universalism" were driven by the binary operationalization used to capture it empirically. By using IMaC to capture the nuance missed by the binary measure one will also capture a more nuanced reality. Wallensteen found that "universalist" periods saw less pacific major-minor relationships, (1984, 247-249, 255). Schahczenski found further indicators of the continued militancy of all types of international relationships under "universalism," with the exception of major-major $(1991,306)$. To put it simply the regulation inherent in "universalism" did not produce peace outside the circle of major powers.

Both Wallensteen and Schahczenski posit that major power cooperation is associated with increased interference in minor power issues and increased extrasystemic adventures $(1984,1991)$. The peace among the major powers is bought at the expense of minor powers and polities outside the system. This echoes past arguments made against European Congress systems (Advocate of Peace 1922). However, these results may be revised now.

The findings in Table 4 indicated that at least 37 years coded by Wallensteen as "universalism" are actually characterized by policies that fit the "Particularist Regulation" IMaC category. This is the second most conflictual category. Also, 8 
years of "Particularism" fall in the "Managerial Regulation" category, the second most cooperative category. This gives reasons to argue that the Wallensteen and Schahczenski findings, rather than representing policy choices, may be artifacts of the lack of granularity in the original binary variable.

To evaluate this argument, I replicate some of Wallensteen's and Schahczenski's 1816-1976 analyses but using IMaC categories. The only change is that I used the updated Correlates of War data for war and dispute information. In Table 6 , I focus on the findings Wallensteen reported in Table II $(1984,246)$. The first two columns are for "universalism" and "particularism." The rest are IMaC categories. The findings indicate that the two most cooperative IMaC categories see fewer major-minor wars compared to the two least cooperative categories. Indeed, the average number of wars per category behaves as the explanatory story briefly presented in this manuscript would expect, with the average increasing as managerial coordination decreases.

TABLE 6. REPLiCATING WALLENSTEEN, 1816-1976

\begin{tabular}{|c|c|c|c|c|c|c|c|}
\hline & Universalism & Particularism & $\begin{array}{l}\text { "Universalist } \\
\text { Regime" }\end{array}$ & $\begin{array}{l}\text { t"Managerial } \\
\text { Regulation" }\end{array}$ & $\begin{array}{l}\text { "Regulatory } \\
\text { Indifference" }\end{array}$ & $\begin{array}{l}\text { "Particularist } \\
\text { Regulation" }\end{array}$ & $\begin{array}{l}\text { "Adversarial } \\
\text { Particularism" }\end{array}$ \\
\hline $\begin{array}{l}\text { Major- } \\
\text { Major } \\
\text { Wars }\end{array}$ & 0 & 10 & 0 & 0 & 1 & 0 & 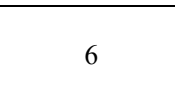 \\
\hline $\begin{array}{l}\text { Major- } \\
\text { Minor } \\
\text { Wars }\end{array}$ & 10 & 16 & 0 & 7 & 4 & 25 & 14 \\
\hline $\begin{array}{l}\text { Minor- } \\
\text { Minor } \\
\text { Wars }\end{array}$ & 18 & 30 & 0 & 11 & 3 & 23 & 11 \\
\hline $\begin{array}{l}\text { Length } \\
\text { Years } \\
\text { Average }\end{array}$ & 86 & 74 & 9 & 36 & 14 & 79 & 23 \\
\hline $\begin{array}{l}\text { Major/ } \\
\text { Major } \\
\text { Average }\end{array}$ & 0 & 0.21 & 0 & 0 & 0.07 & 0.10 & 0.26 \\
\hline $\begin{array}{l}\text { Major/ } \\
\text { Minor } \\
\text { Average }\end{array}$ & 0.11 & 0.21 & 0 & 0.19 & 0.28 & 0.31 & 0.60 \\
\hline $\begin{array}{l}\text { Minor/ } \\
\text { Minor }\end{array}$ & 0.20 & 0.40 & 0 & 0.30 & 0.21 & 0.29 & 0.47 \\
\hline
\end{tabular}

When it comes to minor-minor wars "Universalist Regime" experienced none, but "Managerial Regulation" experienced an average similar to that of "Particularist Regulation." Both were substantially smaller than the average of "Adversarial Particularism." Using IMaC we can see that major powers do avoid warfare with the minor powers during periods of regulation via managerial coordination.

In Table 7, I replicate part of the analyses of conflict frequency presented by Schahczenski in Table IV (1991, 307). For the sake of brevity, I collapse his specific periods of "universalism" and "particularism" into the parent categories. The first two columns contain Schahczenski's numbers. We immediately see that the 
average number of disputes in "universalism" periods is larger than that of "particularism" periods. This is also the case with Extra-systemic wars.

TABLE 7. REPLICATING SCHAHCZENSKI's ANALYSIS, 1816-1976

\begin{tabular}{|c|c|c|c|c|c|c|c|}
\hline & Universalism & Particularism & $\begin{array}{c}\text { "Universalis } \\
\text { Regime" }\end{array}$ & $\begin{array}{r}\text { "Managerial } \\
\text { Regulation" }\end{array}$ & $\begin{array}{l}\text { "Regulatory " } \\
\text { Indifference" }\end{array}$ & $\begin{array}{l}\text { "Particularist } \\
\text { Regulation" }\end{array}$ & $\begin{array}{l}\text { t "Adversarial } \\
\text { Particularism" }\end{array}$ \\
\hline $\begin{array}{l}\text { Dispute } \\
\text { Frequency }\end{array}$ & $594(6.9)$ & $378(5.1)$ & $28(3.1)$ & $225(6.25)$ & 132(9.4) & $889(11.2)$ & 257(11.1) \\
\hline $\begin{array}{l}\text { Interstate } \\
\text { Wars }\end{array}$ & $25(0.29)$ & $38(0.51)$ & $0(0)$ & $18(0.50)$ & $8(0.57)$ & $56(0.70)$ & $31(1.34)$ \\
\hline $\begin{array}{l}\text { Major } \\
\text { Power } \\
\text { Wars }\end{array}$ & $\mathbf{0 ( 0 )}$ & $11(0.14)$ & $0(0)$ & $7(0.19)$ & $5(0.35)$ & $33(0.41)$ & $20(0.86)$ \\
\hline $\begin{array}{l}\text { Extra- } \\
\text { Systemic } \\
\text { Wars }\end{array}$ & 33(0.38) & $17(0.22)$ & $6(0.66)$ & $22(0.61)$ & $5(0.35)$ & $48(0.60)$ & $11(0.47)$ \\
\hline Years & 86 & 74 & 9 & 36 & 14 & 79 & 23 \\
\hline
\end{tabular}

period means in parentheses

Using IMaC we can see that the most cooperative category, "Universalist Regime," is bereft of both interstate and major power wars. As we decrease in coordination, the average numbers per conflict type go up. Still the second most cooperative category, "Managerial Coordination," experiences a smaller average number of wars compared to the less cooperative categories. "Adversarial Particularism," the least cooperative category, is also the most war-prone. These patterns also hold for dispute frequency. Using $\mathrm{IMaC}$ we find that managerial coordination is not just associated with less warfare in the interstate system, but also with a decrease in militarized disputes. The past findings of Wallensteen and Schahczenski were driven by operationalization rather than empirical dynamics. When the major powers engage in managerial coordination, the interstate system becomes more pacific.

This is not the case with polities outside that system. Extra-systemic wars take place in all categories of IMaC. Indeed, the two most cooperative IMaC categories do not experience different frequencies of extra-systemic warfare compared to the least cooperative category. In this case both the Wallensteen and Schahczenski findings are independent of operationalization. Thus, using IMaC leads to the confirmation of one past finding: the lack of any positive influence of managerial coordination outside the interstate system. But it also leads to the revision of another past finding. Managerial coordination is associated not just with peace among the major powers, but also with peace between the major powers and minor powers, and between minor powers.

\section{CONCLUSION}


Wallensteen's "universalism" and "particularism" concept provided peace and conflict studies with one of the few system level variables for capturing the quality of major power regulation of the use of force in international politics. Limitations of the original concept restricted the usefulness of the variable to the 1816-1976 period. Because there are no alternative system level variables that capture what Wallensteen captures, I embarked on enriching and extending the original concepts.

To do this, I focused on a specific set of policies that predominate in periods of "universalism," major power managerial coordination. I presented an explanatory story about why the major powers would engage in managerial coordination, and how they use it to regulate the use of force in the international system. I then presented a novel measurement instrument that captures the variation in managerial coordination from "universalism" to "particularism" and situations in between. This is the scale of interstate managerial coordination (IMaC). This instrument is replicable, has more granularity than the original variable, and can be used in the 1715-2010 period.

I then used this instrument to resolve a puzzle located by studies using the original binary variable. This was that periods of "universalism" did not differ from periods of "particularism" when it came to conflict between minor and major powers, between minor powers, and major power extra-systemic wars. Using IMaC confirmed original findings that regulation of the use of force in the interstate system does not extend beyond its bounds. But it also revised the original finding that the regulation of the use of force via managerial coordination between the major powers did not extend beyond their circle of peers. Instead we find that managerial coordination fosters pacific relations between major powers and minor powers, and between minor powers. This indicator supports the theoretical sketch briefly developed here about why major powers engage in managerial coordination.

The specific focus in this manuscript was to provide the basics of an explanatory story of why states, in this case focused on major powers, would engage in managerial coordination, and why we would expect managerial coordination to dampen the use of force in interstate relations. This explanatory story was the basis for developing the concept of managerial coordination and based on it the measurement instrument of IMaC. By necessity the exploration of the causes and consequences of managerial coordination was brief. Prior work has looked at the consequences of managerial coordination for interstate peace, but needs to be updated and expanded (Travlos 2014). A fuller analysis of the causes of managerial coordination, focusing on aversion to war, and an empirical evaluation of that association is also required. Lastly, an application of the concept to groups of minor powers, like the Scandinavian states, is also required. These are all topics for future projects using IMaC.

Finally, the use of IMaC opens up three avenues of potential future research beyond the immediate focus on interstate conflict and the avoidance of war. One is 
to evaluate the role IMaC may have in the decline of war that has been noted by several scholars (The Forum: The Decline of War 2013). A second tack for future research is to explore the relationship between the $\mathrm{IMaC}$ and the concept of satisfaction. The field lacks a system level variable of satisfaction (Kang and Gibler 2013), and IMaC might meet that need. Finally, the opening of the "black box" of peace raises the question about the relationship between IMaC and the quality of interstate peace (Goertz et al. 2016; Wallensteen 2015).

\section{REFERENCES}

Advocate of Peace. 1922. "Europe's Poisonous Remedies." Advocate of Peace 84 (11): 369-370.

Bercovitch, Jacob and Gerald Schneider. 2000. "Who Mediates? The Political Economy of International Conflict Management." Journal of Peace Research 37(2): 145-165.

Braumoeller, Bear F. 2012. The Great Powers and the International System: Systemic Theory in Empirical Perspective. New York, N.Y: Cambridge University Press.

Boix, Charles. 2011. "Democracy, Development, and the International System." American Political Science Review 105(4): 809-828.

Bueno de Mesquita, Bruce, Alastair Smith, Raymond R. Siverson and James D. Morrow. 2003. The Logic of Political Survival. Cambridge M.A: The MIT Press.

Buhaug, Halvard and Neils P. Gleditsch. 2006. "The Death of Distance? The Globalization of Armed Conflict." In Territoriality and Conflict in an Era of Globalization edited by Miles Kahler and Barbara F. Walter, 187-216. New York N.Y: Cambridge University Press.

Chan, Steven. 2005. 'Discerning the Causal Relationships between Great Powers' Membership in Intergovernmental Organizations and Their Initiation of Militarized Disputes." Conflict Management and Peace Science 22(3): 239-256.

Chiba, Daina, Carla M. Machain and William Reed. 2014. "Major Powers and Militarized Conflict." Journal of Conflict Resolution 58(6): 976-1002.

Clark, Christopher. 2012. The Sleepwalkers: How Europe Went to War in 1914. New York N.Y: Harper-Collins.

Colaresi, Michael P., Karen Rasler and William R. Thompson. 2008. Strategic Rivalries in World Politics: Position, Space and Conflict Escalation. New York N.Y: Cambridge University Press.

Correlates of War Project.2011. State System Membership List, v2011. http://cor relatesofwar.org

Delahunty, Robert J. 2007. "Paper Charter: Self-Defense and the Failure of the United Nations Collective Security System.” Catholic University Law Review 
University of St. Thomas Legal Studies Research Paper No. 07-01.

Gleditsch, Neils P. 2013. "The Forum: The Decline of War." International Studies Review 15(3): 396-419.

Gibler, Douglas M. 1999. "An Extension of the Correlates of War Formal Alliance Data Set, 1648-1815." International Interactions 25(1): 1-28.

Gibler, Douglas M. 2009. International Military Alliances, 1648-2008. Washington DC: CQ Press.

Gochman, Charles S. 1993. "The Evolution of Disputes." International Interactions 19(1/2): 49-76.

Goertz, Gary, Paul F. Diehl and Alexandru Balas. 2016. The Puzzle of Peace. New York N.Y: Oxford University Press.

Hansen, Holley E., Sara M. Mitchell and Stephen C. Nemeth. 2008. "International Organization Mediation of Interstate Conflicts: Moving Beyond the Global versus Regional Dichotomy." Journal of Conflict Resolution 52(2): 295-325.

Hensel, Paul R. 2001. "Contentious Issues and World Politics: The Management of Territorial Claims in the Americas, 1816-1992." International Studies Quarterly 45(1): 81-109.

Hensel, Paul R. 2005. Multilateral Treaties of Pacific Settlement (MTOPS) Data Set, version 1.4. http://data.icow.org

Herz, John H. 1950. "Idealist Internationalism and the Security Dilemma." World Politics 2(2): 171-201.

Jervis, Robert. 1978. "Cooperation under the Security Dilemma." World Politics 30(2): 167-174.

Jervis, Robert. 1985. "From Balance to Concert: A Study of International Security Cooperation." World Politics 38(1): 58-79.

Kang, Choong-Nam and Douglas M. Gibler. 2013. "An Assessment of the Validity of Empirical Measures of State Satisfaction with the Systemic Status Quo." European Journal of International Relations 19(4): 695-719.

Kaldor, Mary. 2013. "In Defense of New Wars." Stability: International Journal of Security and Development 2(1): Art. 4.

Klein, John P., Gary Goertz and Paul F. Diehl. 2006. "The New Rivalry Dataset: Procedures and Patterns.” Journal of Peace Research 43(3): 331-348.

Langer, William L. 1980. An Encyclopedia of World History $5^{\text {th }}$ Edition. Boston M.A: Houghton Mifflin Company.

Leeds, Brett A., James M. Ritter, Sara M. Mitchell and Andrew G. Long. 2002. “Alliance Treaty Obligations and Provisions, 1815-1944." International Interactions 28(3): 237-260.

Leeds, Brett A. 2003. "Do Alliances Deter Aggression? The Influence of Military Alliances on the Initiation of Militarized Interstate Disputes." American Journal of Political Science 47(3): 427-439.

Levy, Jack S. 1994. Great Power Wars, 1495-1815. Inter-University Consortium 
for Political and Social Research Volume 9955. New Brunswick, NJ.

Levy, Jack S. and William R. Thompson. 2011. Causes of War. New York N.Y: John Wiley and Sons.

Levy, Jack S. and John A. Vasquez (Eds.). 2014. The Outbreak of the First World

War: Structure, Politics, and Decision-Making. New York N.Y: Cambridge University Press.

Oneal, John R., Bruce Russett and Michael L. Berbaum. 2003. "Causes of Peace: Democracy, Interdependence, and International Organizations, 1885-1992.”

International Studies Quarterly 47(3): 371-393.

Rabb, Theodore K. 1975. The Struggle for Stability in Early Modern Europe. New York N.Y: Oxford University Press.

Raymond, Gregory A. 1997. "Problems and Prospects in the Study of International Norms." Mershon International Studies Review 41(2): 205-245.

Resnick, Uri. 2013. Dynamics of Asymmetric Territorial Conflict: The Evolution of Patience. New York N.Y: Palgrave Macmillan.

Richardson, James L. 1994. Crisis Diplomacy: The Great Powers since the MidNineteenth Century. New York N.Y: Cambridge University Press.

Sarkees, Meredith R. and Frank W. Wayman. 2010. Resort to War: 1816-2007. Washington D.C: CQ Press.

Schahczenski, Jeffrey J. 1991. "Explaining Relative Peace: Major Power Order, 1816-1976.” Journal of Peace Research 28(3): 295-309.

Schroeder, Paul W. 1994. The Transformation of European Politics 1763-1848. Oxford N.Y: Oxford University Press.

Senese, Paul D. and John A. Vasquez. 2008. The Steps to War: An Empirical Study. Princeton N.J: Princeton University Press.

Siverson, Randolph M. and Michael D. Ward. 2002. "The Long Peace: A Reconsideration." International Organization 56(3): 679-691.

StataCorp. 2013. Stata Statistical Software: Release 13. College Station, TX: Stata Corp LP.

Steiner, Barry H. 2004. Collective Preventive Diplomacy: A Study in International Conflict Management. Albany N.Y: State University of New York Press.

Travlos, Konstantinos. 2014. "From warmongers to peacebuilders: major power managerial coordination and the transformation of international relations, 1715-2001." (PhD Dissertation, University of Illinois at Urbana-Champaign). Valeriano, Brandon. 2009. "The Tragedy of Offensive Realism: Testing Aggressive Power Politics Models.” International Interactions 35(2): 179-206.

Valeriano, Bandon and John A. Vasquez. 2010. "Identifying and Classifying Complex Interstate Wars.” International Studies Quarterly 54(2): 561-582.

Valeriano, Brandon and Ryan C. Maness. 2015. Cyber War versus Cyber Realities: Cyber Conflict in the International System. New York N.Y: Oxford University Press. 
Vasquez, John A. 1983. The Power of Power Politics: A Critique. New York N.Y: Rutgers University Press.

Vasquez, John A. 1993. The War Puzzle. New York N.Y: Cambridge University Press.

Vasquez, John A. and Douglas M. Gibler. 2001. "The Steps to War in Asia, 19311945." Security Studies 10(3): 1-45.

Vasquez, John A. and Choong-Nam Kang. 2012. "How and Why the Cold War became a Long Peace: Some Statistical Insights." Cooperation and Conflict 48(1): 28-50.

Wallensteen, Peter. 1984. "Universalism vs. Particularism: On the Limits of Major Power Order." Journal of Peace Research 21(3): 243-257.

Wallensteen, Peter. 2015. Quality Peace: Peacebuilding, Victory and World Order. New York, N.Y: Oxford University Press.

Zinnes, Dinna A. 1980. "Prerequisites for the Study of System Transformation." In Change in the International System edited by Ole R. Hoslti, 3-21. Boulder C.O: Westview Press. 


\section{ENDNOTES}

1 The author would like to thank the two anonymous reviewers for their comments and recommenddations. I would also like to thank John A. Vasquez, Paul F. Diehl, Peter Wallensteen, Paul Huth, Daniel Geller, and Gennady Rudkevich for their contributions to the development of this project.

2 The previous iteration of this measurement instrument was called scale of major power managerial coordination intensity (MPMCI). An anonymous reviewer noted that the principles could also apply to minor powers and suggested the term scale of interstate managerial coordination (IMaC). I am grateful to Peter Wallensteen for explaining the process used in the original paper to me.

4 On useful reviews of the literature and debate on the concept of "new wars" see Kaldor (2013) and Levy and Thompson (2010).

5 Essentially the transformation in the regulation of interstate war noted by Schroeder (1994), must follow the transformation on the question of the monopoly of the use of force noted in by Rabb (1975).

6 Elements of the explanatory story for future analysis include the impact on the causal story of the ability of elites in government to overhaul their wining coalition (Braumoeller 2012), and the ability of the major powers to insulate themselves from minor power issues (Steiner 2004)

7 No such alliances exist in ATOP after 1945.

8 Correlates of War Project. 2008. "State System Membership List, v2011." Online, http://correlates ofwar.org. I make a significant change. COW lists France as a major power in 1816-1818 and 1871-1873. But that is a fallacy because large areas of France were occupied during the periods as a result of military defeats. Since COW does not list France as a major power in 1941-1944, or Germany from 1918 to 1925 , both of which faced a similar situation, I see no justification for not doing so with France in 1816-1818 and 1871-1873.

9 The ATOP id numbers for the managerial alliances are 1035 (The Quadruple Alliance), 1110 (1840 Treaty Concerning Mehmet Ali), 2095 (1921 Treaty between the UK, France, Japan, and the United States)

10 The ATOP id numbers for adversarial alliances are 1065, 1160, 1165, 1170, 1180, 1190, 1215, 1265, 1270, 1295, 1300, 1350, 1365, 2025, 2040, 2350, 2355, 2360, 2395, 2535, 2540, 2550, 2555. There is one alliance in the ATOP dataset that has explicit major power targets, has more than one major power member, and is not coded as adversarial. This is the alliance with ATOP id. 2310. The reason is that the explicit targets (France, Germany) are also members of the alliance. The alliance was a non-aggression treaty with a defensive clause concerning Belgium. It lasted from 1925 to 1937. Three ATOP alliances that have at least two major power members, and do not have explicit major power targets but are coded as adversarial are the 1856 alliance for guaranteeing the Paris Treaty that ended the Crimean War, which implicitly targets Russia as the only excluded power (ATOP id. 1195), the 1914 agreement among the entente powers not to sign individual peace treaties with the Central Powers (ATOP id. 2015), and NATO before 1990.

11 Their Gibler id numbers are 1055, 1060, 1066, 1067, 1070, 1081, 1087, 1095, 1125, 1127, 1128, 1131.

12 Anglo-Russian Rivalry (1778-1956), Soviet-United States Rivalry (1945-1989), Chinese-US rivalry (1949-1972), Chinese-Soviet Rivalry (1958-1989), Japan-China Rivalry (1996-2011), China-Untied States Rivalry (1996-2011), and Russia-United States Rivalry (2007-2011).

13 The ATOP Ids of these alliances are 3030, 3055, 3200, 3375, 2535, 2575, 3130, 3180, 3260, 3222, $3460,3470,3740,3755,3815$

${ }_{15}$ Available online at http://data.icow.org

15 The Online Appendix and Replication Data are available at http://ktravlospolisci.blogspot.com.tr/p/ replication-data.html 